\title{
Running on the spot: NZ's record in news media gender equity
}

\begin{abstract}
ABSTRACI
This article reports New Zealand's performance in the latest, 2010 round of the Global Media Monitoring Project (GMMP) covering 108 countries. Using quantitative and qualitative content analysis the GMMP measures the representation and participation of women in the news media. The findings demonstrate that gender inequality remains a defining characteristic of daily news content around the world. It is concerning that in 15 years of the GMMP, New Zealand has generally stood still while overall GMMP results show a continuing steady increase in the number of women featuring as news subjects and reporters. Indeed, despite more women working as reporters in New Zealand, the lack of progress was evident in the number of female news subjects. The picture emerging from data in 2010 is of increasingly feminised newsrooms in which women's experiences and views are still seen and heard much less frequently than male voices in almost all news topics. Worse, women are virtually absent in sports and politics, areas dominating the Kiwi news agenda. We ask why women remain so consistently under-represented in mainstream news and review some suggested solutions to that under-representation.
\end{abstract}

Keywords: equality, gender, global news data, journalists, news media, reporting, women's representation,

\section{MARGIE COMRIE \\ Massey University}

KATE MCMILLAN

Victoria Unviersity

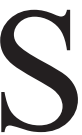

INCE 1995, the Global Media Monitoring Project (GMMP) has scrutinised women's representation and participation in the world's news media. It is the largest, longest-running, international gender audit of the news. The number of countries participating grew significantly between 196 PACIFIC JOURNALISM REVIEW 19 (2) 2013 
1994 and 2009 (from 71 to 108), but data have remained remarkably consistent. Across all countries over the 15 -year data gathering period, women continue to make up a small proportion (24 percent in 2010) of people featured in newspaper, radio, television and internet news stories. When women do appear they are concentrated into stories on topics commonly understood to be less politically significant than those in which men usually predominate. Despite optimism that more women in the newsroom would shift this imbalance, improvements in coverage world-wide have been sluggish and, in New Zealand's case, non-existent.

This article presents the 2010 data on women's representation and participation in the news media, showing how New Zealand is no longer a global leader in media gender equity. We begin with the GMMP's origins, goals and methodology, before presenting the latest New Zealand data, comparing them with previous results and the general global picture. A concluding section considers contending explanations for the continuing gender imbalance in New Zealand news, and revisits the range of strategies available to improve the representation and participation of women in the news media.

New Zealand has participated in each of the four GMMP surveys since the project began. While data presented below is depressingly familiar from previous reports, the continuity with previous findings, and with those from other studies here and abroad, highlights the need for ongoing work to increase gender awareness among both producers and consumers of news.

\section{The Global Media Monitoring Project: Background and goals}

The GMMP has been driven by social activists since its inception at a 1994 women's conference. When Canadian organisation Media Watch coordinated the first GMMP, its goals were to 'build solidarity, create media awareness, and encourage media monitoring skills on an international level' (World Association for Christian Communication and Global Media Monitoring Project, 2013). Central to the project's conception was the belief that, as the news media have enormous power to both reinforce and challenge existing power relations in society, a news media in which women are largely absent will perpetuate women's social, political and economic inequality. Since 1994, the GMMP has encouraged using the results to advocate for journalistic practices which avoid gender discrimination and increase the accurate and proportional representation of women in the news. 
Three broad categories of gender inequality in the news (Byerly, 2004) are apparent from the GMMP data: language or imagery perpetuating gender stereotypes; significant differences between the proportion of men and women who appear as news subjects and sources across a range of story topics; and, for those who present and report the news, significant gender effects in the allocation of news roles. All three types of inequality, but especially the small percentage of women news subjects and sources, have proved resistant to change.

Claims that much of the news media's power lies in their agenda-setting (Coleman, McCombs, Shaw \& Weaver, 2008) and framing functions (e.g. Entman, 2007) have been complicated by the digital media revolution, but the argument that women's interests suffer if their experiences and voices are largely excluded from the pages, screens and airwaves where much public debate occurs remains persuasive.

Attempts to explain women's under-representation in the news media quickly run into profound and divisive questions about the gendered nature of institutional, ideational and cultural power, including that of the news media-ideas we shall touch on in the discussion. Journalists argue that deliberately aiming to increase women's presence in the news runs contrary to objective journalistic practice and established news values. However, author of the global GMMP reports, Margaret Gallagher (2010) contends such journalistic practices and values are often 'simply a surface expression of much more tangled gender-based evaluations and priorities' ( $p$. iii). The GMMP sees collecting data to map women's under-representation in the news media as a necessary but only first step in understanding underlying processes. Change will require further scholarly work and activism in multiple domains.

\section{GMMP method}

The GMMP is essentially a one-day 'snapshot' every five years of each participating country's news media. Data for the 2010 report was collected on 10 November 2009. The content of major newspapers, radio stations and television channels has been analysed since 1995, but the 2010 report also includes internet news sites. To ensure results are comparable across nations, a complex weighting system reflects differing population figures, numbers of media and variations in media access. For data gathering, countries are grouped into media 'bands': those with more news media outlets are required

198 PACIFIC JOURNALISM REVIEW 19 (2) 2013 
to sample a larger number of news products than countries with fewer media outlets. Within each band, monitors are assigned a maximum and minimum number of media to analyse. A detailed description of the method is available on http://www.whomakesthenews.org/gmmp-2010-reports.html.

New Zealand was considered to be a Band 3 country for television and Band 4 for radio and print media. This required those collecting New Zealand's data to select between three to five television news broadcasts and between five to eight radio news broadcasts and newspapers for coding. Accordingly, the team analysed six daily newspapers, news on seven radio stations, four free-to-air prime time television news programmes and six internet news sites. We made the following selections.

- The four metropolitan dailies and two major regional newspapers: New Zealand Herald, Dominion Post, The Press, Otago Daily Times, Waikato Times and Manawatu Standard. These also reflected the main newspaper ownership patterns (Fairfax, APN and Allied Press).

- The major bulletins on free-to-air television channels: TVNZ's One News (6-7pm), TV3's 3News (6-7pm), Prime TV news (5.30-6.00pm) and MTS's Te Kaea, Māori TV news (11.00pm subtitled version of the 7.30-8pm broadcast).

- Seven main morning radio bulletins: the 7am national news on Radio New Zealand, Newstalk ZB and Radio Live; local news on Newstalk ZB Palmerston North (7.05am); Radio One student radio Dunedin (7am); Kia Ora FM at 7am (Māori language news provided by MaiFM); Waatea News on National Radio at 6.45am (content at that stage provided by Auckland-based Waatea News). Māori language radio news was professionally translated for the team.

- Six internet news sites were monitored between 7 and 10am: Stuff. co.nz, nzherald.co.nz, tvnz.co.nz, tv3.co.nz, radionz.co.nz and newstalkzb.co.nz.

Teams in each country were supplied templates for each media type analysed, accompanied by detailed guides on sample selection, what items to code (for instance not newspaper editorials or letters and not television's weather report), and how to code each element of each story. Coders practised on news items beforehand and coding protocols were provided early so coordinators could ask questions about categories to ensure greater 
standardisation. Coding was conducted in pairs with the whole team assembled on the day, discussing and sharing difficult coding decisions.

Analysis was largely quantitative with some qualitative elements, and focused on revealing the presence and portrayal of women in various aspects of news. First, stories were coded according to: topic (52 subjects under eight larger categories: politics and government; economy; science and health; social and legal; crime and violence; celebrity, arts, media and sports; the girlchild; and 'other'), scope (local, national, international and mixed), reference to gender equality or human rights policy, and gender of the reporter. Then people in the news (news subjects) were analysed for sex, age, occupation and function in the news story (including subject, spokesperson, expert and eye witness). Coders also recorded whether news subjects were identified in terms of their family relationships, whether they were a victim or survivor and whether they were directly quoted and, in the case of newspapers, whether they had an accompanying photograph. Coders also noted if women were central to the story, whether the story highlighted issues of gender inequality and whether it challenged gender stereotypes.

\section{Results}

Overall, the 2010 GMMP results revealed no improvement in the way women made the news in New Zealand media and some evidence that this country is tending to slip lower in the global gender equity media league tables. Here we first consider news topics, gender of reporters and presenters, and gender of news subjects, their occupations and function in the story. Then data on the gender of victims in the news and the way news subjects are identified by family status are presented before a brief consideration of news images.

\section{News topics}

The eight monitors analysed a total of 187 stories. In New Zealand, the big news stories of the data-gathering day were: MPs' spending, especially 'travel perks' for partners of Rodney Hide and David Carter; the then Māori Party MP Hone Harawira's email tirade about Pākehā; the court case of a man accused of killing and raping two women and burying them under his house; fashion and racing coverage of the NZ Trotting cup; and, internationally, the 20-year anniversary of the fall of the Berlin Wall.

Table 1 summarises story topics for New Zealand (the bolded figures on the top line of each box) and the combined global figures (the bottom line in

200 PACIFIC JOURNALISM REVIEW 19 (2) 2013 


\begin{tabular}{|c|c|c|c|c|c|}
\hline \multirow{2}{*}{ Topic } & \multicolumn{2}{|c|}{ Total stories } & \multirow{2}{*}{ Print } & \multirow{2}{*}{ Radio } & \multirow{2}{*}{ Television } \\
\hline & Stories & Percentage & & & \\
\hline Politics and government & $\begin{array}{c}46 \\
4685\end{array}$ & $\begin{array}{l}24.6 \% \\
28.0 \%\end{array}$ & $\begin{array}{l}25 \% \\
32 \%\end{array}$ & $\begin{array}{l}33 \% \\
28 \%\end{array}$ & $\begin{array}{l}20 \% \\
26 \%\end{array}$ \\
\hline Sports, celebrities, arts & $\begin{array}{c}45 \\
1773\end{array}$ & $\begin{array}{c}\mathbf{2 4} \% \\
10.6 \%\end{array}$ & $\begin{array}{c}10 \% \\
7 \%\end{array}$ & $\begin{array}{l}15 \% \\
10 \%\end{array}$ & $\begin{array}{l}44 \% \\
14 \%\end{array}$ \\
\hline Economy & $\begin{array}{c}28 \\
2949\end{array}$ & $\begin{array}{c}15 \% \\
17.6 \%\end{array}$ & $\begin{array}{c}9 \% \\
16 \%\end{array}$ & $\begin{array}{l}21 \% \\
21 \%\end{array}$ & $\begin{array}{l}18 \% \\
17 \%\end{array}$ \\
\hline Crime and violence & $\begin{array}{c}27 \\
3329\end{array}$ & $\begin{array}{l}14.4 \% \\
19.9 \%\end{array}$ & $\begin{array}{c}16 \% \\
19\end{array}$ & $\begin{array}{l}18 \% \\
18 \%\end{array}$ & $\begin{array}{l}11 \% \\
22 \%\end{array}$ \\
\hline Social and legal & $\begin{array}{c}26 \\
3329\end{array}$ & $\begin{array}{l}13.9 \% \\
12.8 \%\end{array}$ & $\begin{array}{l}25 \% \\
15 \%\end{array}$ & $\begin{array}{l}13 \% \\
12 \%\end{array}$ & $\begin{array}{c}3 \% \\
10 \%\end{array}$ \\
\hline Science and health & $\begin{array}{c}14 \\
2146\end{array}$ & $\begin{array}{l}7.5 \% \\
9.2 \%\end{array}$ & $\begin{array}{l}14 \% \\
10 \%\end{array}$ & $\begin{array}{l}0 \% \\
9 \%\end{array}$ & $\begin{array}{l}4 \% \\
9 \%\end{array}$ \\
\hline Other & $\begin{array}{c}1 \\
274\end{array}$ & $\begin{array}{l}7.5 \% \\
9.2 \%\end{array}$ & $\begin{array}{l}1 \% \\
1 \%\end{array}$ & $\begin{array}{l}0 \% \\
1 \%\end{array}$ & $\begin{array}{l}0 \% \\
2 \%\end{array}$ \\
\hline The girl-child & $\begin{array}{c}0 \\
39\end{array}$ & $\begin{array}{c}\mathbf{0} \% \\
0.2 \%\end{array}$ & $\begin{array}{c}\mathbf{0} \% \\
\text { Below 1\% }\end{array}$ & $\begin{array}{c}0 \% \\
\text { Below 1\% }\end{array}$ & $\begin{array}{c}\mathbf{0} \% \\
\text { Below 1\% }\end{array}$ \\
\hline TOTAL & $\begin{array}{c}187 \\
16734\end{array}$ & $\begin{array}{l}99.9 \% \\
99.9 \%\end{array}$ & $\begin{array}{l}100 \% \\
100 \%\end{array}$ & $\begin{array}{l}100 \% \\
99 \%\end{array}$ & $\begin{array}{l}100 \% \\
100 \%\end{array}$ \\
\hline
\end{tabular}

Note: New Zealand totals and percentages for print, radio and television are in bold.

italics). The global figures include New Zealand as one of the 108 participating countries. The table first covers all stories (except internet) giving both numbers and percentages in each topic. Then print, radio and television figures are separated out with percentages rounded to the nearest whole number as provided by the GMMP reporting team and used in other tables in the article.

Across all the New Zealand media, political stories and sports/celebrity stories vied for top-equal place - nearly half of all stories. However there was a considerable difference among media, especially in the sports/celebrity category -44 percent of stories on television compared to 15 percent on radio and just 10 percent in newspapers. The vast majority of sports/celebrity stories were in fact sports items and the lower figure for newspapers is largely explained by the coding protocol excluding their sports sections. Politics and government stories made up 33 percent of radio stories, 25 percent of print stories and 20 percent of stories on television. Economic stories (15 percent of all coverage) closely followed by crime/violence and social/legal stories (both 14 percent) were the next most important topics. Newspapers ran fewer 
economic stories and more social/legal stories ( 24 percent) than radio and television. Health and science stories made up 7.5 percent of the total; they featured more in newspapers than on television and not at all on radio news.

The average global figures show the two top topics were politics and government ( 28 percent) and crime and violence ( 20 percent). This country's emphasis on celebrity/sports stories is unusual in world terms - the global figure was 11 percent (Australia's overall media figure was 23 percent, with 26 percent on television news). As will be seen, New Zealand's addiction to sports coverage impacts on the number of women featuring in the news. The next largest discrepancy between global and New Zealand figures was in crime and violence stories, where New Zealand's 14 percent of stories was below the global average.

\section{Who reports the news?}

Of the 102 stories where reporters could be identified, 47 (46 percent) were written by female journalists, up from 42 percent in 2005. Women were responsible for exactly half the stories in New Zealand newspapers and radio, and for 39 percent (17 of 44) of television news stories. Very few (16 percent) of the news stories in our online sample identified the reporter, but of those that did, 60 percent were male.

Globally, women were responsible for 37 percent of all stories; 33 percent of newspaper stories, 37 percent of radio stories and 44 percent of television items. This worldwide percentage of female reporters has risen from 28 percent in 1995 and increased in 2010 for every area of the world except the Pacific. In the Pacific, the overall percentage of female reporters declined in 2010, largely because Australia re-joined the GMMP in 2010; 34 percent of the Australian reporters were female. New Zealand can therefore be pleased with the high representation of female reporters in every medium but television, where the figure reflects the number of male-dominated sports stories.

It was in the category of New Zealand sports/celebrity reporting that female journalists were least represented; men reported 81 percent of these stories. However, women were responsible for more than half the economic items ( 58 percent) and social/legal stories ( 53 percent). Women also reported just under half ( 49 percent) of crime and violence items, 44 percent of political stories and 43 percent of science and health stories. The New Zealand figures differed from global results where the pattern in 2010 (and in 2000) was that 
women are least likely to report politics and crime/violence stories-topics high on the news agenda. Conversely, global figures show science/health and social/legal stories (generally of lower news value) are most likely to be reported by women.

Table 2: New Zealand: presence of both sexes as subjects of news
\begin{tabular}{|l|c|c|c|c|c|c|c|c|}
\hline \multirow{2}{*}{ Sex } & \multicolumn{2}{|c|}{ All } & \multicolumn{2}{c|}{ Print } & \multicolumn{2}{c|}{ Radio } & \multicolumn{2}{c|}{ Television } \\
\cline { 2 - 9 } & Stories & Percent & Stories & Percent & Stories & Percent & Stories & Percent \\
\hline Female & 129 & 25 & 71 & 28 & 16 & 30 & 42 & 20 \\
\hline Male & 392 & 75 & 186 & 72 & 38 & 70 & 168 & 80 \\
\hline TOTAL & 521 & 100 & 257 & 100 & 54 & 100 & 210 & 100 \\
\hline
\end{tabular}

\section{Gender of News Subjects}

A working hypothesis of the GMMP is that numerical differences in the presence of men and women in the media not only reflect existing gender inequality but also act to exacerbate it. As Table 2 shows, male presence in New Zealand news - as subjects - was three times that of women. Overall there were 129 women ( 24.8 percent) and 392 men who were the subject of news stories and/or cited in the news. Although no medium performed well, the gender imbalance was highest on television (only 20 percent of news subjects were female); print was next at 28 percent, and female representation on radio was best (although still not equitable) at 30 percent. Across all media, the bulk of stories, and therefore news sources, concerned national news and female presence in these stories was 26 percent. The presence of females was highest in international news stories (38 percent); and least (16 percent) in news which blended national and local aspects, or national and international aspects. Female presence in local stories was 23 percent.

When New Zealand first joined the GMMP, female representation in its news (while poor in relation to population figures) was well above the global figure. In 1995 the figure from the 71 countries involved was 17 percent, By 2000 this had crept up to 18 percent compared with 26 percent in New Zealand. By 2005, 26 percent of news subjects in the New Zealand media were female, compared with a global average of 21 percent. The 2010 report showed the gap narrowing further, the global average now 24 percent, while female representation in New Zealand data showed a slight decline from 2005 to just below 25 percent. 
Table 3: Presence of both sexes in different news topics

\begin{tabular}{|l|c|c|c|c|c|c|}
\hline \multirow{2}{*}{ Topic } & \multicolumn{2}{|c|}{ NZ female } & \multirow{2}{*}{$\begin{array}{c}\text { Global } \\
\text { female }\end{array}$} & \multicolumn{2}{c|}{ NZ male } & \multirow{2}{*}{$\begin{array}{c}\text { Global } \\
\text { male }\end{array}$} \\
\cline { 2 - 3 } & Stories & Percentage & Stories & Percentage & \\
\hline Politics and government & 35 & 21 & $19 \%$ & 130 & 79 & $81 \%$ \\
\hline Sports, celebrities, arts & 19 & 15 & $26 \%$ & 108 & 85 & $74 \%$ \\
\hline Economy & 16 & 22 & $20 \%$ & 50 & 78 & $80 \%$ \\
\hline Crime and violence & 27 & 38 & $24 \%$ & 44 & 62 & $76 \%$ \\
\hline Social and legal & 21 & 36 & $30 \%$ & 39 & 64 & $70 \%$ \\
\hline Science and health & 10 & 33 & $32 \%$ & 21 & 67 & $68 \%$ \\
\hline TOTAL & 129 & 25 & $24 \%$ & 392 & 75 & $76 \%$ \\
\hline
\end{tabular}

The GMMP is also interested in the relationship between gender and which news subjects appear in which news topics. At issue is whether societal expectations about gender roles influence news makers' choices about who to identify as a news subject in particular topics. A consistent finding of New Zealand and global data has been that men and women tend to cluster into story topics broadly consonant with traditional societal assumptions about gender roles.

Table 3 compares New Zealand and global figures for men and women news subjects in the main story topics (organised in order of topic frequency). Here, New Zealand's gender discrepancy was particularly marked in the overall category of sports/celebrity stories (15 percent female representation) and least marked, but still large, in stories about crime and violence ( 38 percent female representation). The global figure for women's presence in sports/celebrity stories was 26 percent and for crime and violence 24 percent. Women's presence in social and legal stories (36 percent for NZ and 30 percent globally) and in science and health stories (NZ 33 percent, global 30 percent) was also comparatively high. In the broad category of politics and government, New Zealand figures of 21 percent were only just ahead of the global 19 percent average. In global results, women's presence was highest (32 percent) in science and health news and social/legal news (30 percent). However, these topics form a very small proportion of the overall news.

Looking at the more specific story topics under each broad topic the picture was more varied. In those specific story types that were most common - general domestic politics and sports stories - women appeared rarely. These stories made up half of all 187 items coded and therefore had the most

204 PACIFIC JOURNALISM REVIEW 19 (2) 2013 
news subjects (113 and 112 respectively). Under GMMP's sports/celebrity category women were news subjects in only 11 percent of stories about sports (there were few New Zealand stories about celebrities and arts). In the political category, women were just 16 percent of news subjects in national and local political stories, and even in stories categorized as 'women in political power and decision-making', women made up only 22 percent of the news subjects. The specific story topic with the next largest number of stories (36) was 'gender-based violence', stories about rape and domestic violence. Here the genders were exactly evenly represented. In the 32 news stories about foreign affairs and international relations, women made up 42 percent of news subjects. In almost all other story topics on which 10 or more stories were coded, women comprised a third or fewer of total news subjects. Exceptions included education stories (14) where female subjects were 51 percent; 'arts and entertainment' (10) with 50 percent of news subjects being women; and non-violent crime (19), where 36 percent of subjects were women. In some story topics the percentage of women was very low indeed. In agriculture and rural economy stories, for example (17 stories), women were 12 percent of news subjects. In only four topic areas (a total of six stories in the sub-topic areas of human rights, gender relationships, global partnerships and legal system) did women make up all the news sources in a story and in each of these there was just one source per story.

\section{Occupation of male and female news subjects and their role in the story} A third GMMP concern is whether gender is reflected in who is presented by the news media as representative of particular occupational groups. News media consistently presenting only or predominantly male news subjects in some occupations and only females in other occupations can act to perpetuate existing stereotypes about gender divisions in the workplace. In terms of occupation of news subjects, the 172 government officials and politicians appeared most frequently in the news; of these, 82 percent were men. Next up were 82 sports players, coaches and referees-just two of these were women. Of 35 activists or NGO workers in the news, 30 percent were female. Thirty three business people made the news, of whom 13 percent were women. Of 30 public servants one third were women. Four of 15 police, military or prison personnel were women, as were three of 14 legal practitioners. Of 10 described only as homemakers, 80 percent were women, while all of 10 
criminals or suspects were male. Half the children, students and those in the news because they were residents close to a news event were female. Other sources were infrequent, although inclined to fit occupational stereotypes - tradespeople, agricultural workers and artisans were all men, as were religious figures. Male celebrities and media figures out-numbered females (4 of 5), more retirees were female and the one prostitute cited was female.

The New Zealand results tended to echo global figures, although with small categories, comparisons are not always useful. As in New Zealand, government officials and politicians made a significant proportion of news subjects globally, and were similarly 83 percent male. Globally, although the female representation among sports players and coaches was a dismal 9 percent, it was still better than New Zealand's 2 percent. The percentage of female business people globally matched New Zealand figures, but our results for female public servants as news subjects (33 percent) were considerably higher than the global 17 percent. Global figures showed women outnumbered men in only two categories, as homemakers and students.

The different functions news subjects fulfill in a news story can act to represent power relations in society, with those who appear as experts or as spokespeople for specific societal groups accorded greater levels of social power than eye witnesses, for example. Again, gender imbalances in the function news subjects play in a story can both mirror and exacerbate existing gender inequality. In terms of their function in the story, most subjects appeared in the news either because the story was about them in some way, or because they were spokespeople. In both these cases, the percentage of women reflected their overall presence in the news (about a quarter). However, of 44 experts cited in New Zealand news, just nine or 19 percent were women. Of the remaining sources, women were far more likely than men to be cited as representing popular opinion, nine of 11 sources, generally in vox pops; four of eight eye witnesses were women as were seven of 17 who provided comments based on their personal experience. The global figures represent a similar pattern.

\section{Constructing 'victims' in the news}

Most studies of gender in the news show women are more likely to be represented as victims than males. The global figures, where there were more than twice as many female victims in the news as male victims, bore out these 
findings. However, of 26 victims cited in New Zealand news, only slightly more than half (14) were women. All seven victims of domestic violence were women, as were the three victims of non-domestic sexual violence or abuse. On the other hand, all six victims of natural disaster or poverty cited were men. Of the five victims of robbery or violence, three were men, but women and men featured equally (two each) as victims of discrimination (of gender, race, ethnicity, religion and so on).

\section{Identity and family status in the news}

Identifying the family status of news subjects can act to identify a person's significance as associational rather than independent. Family status was mentioned in the case of just 7 percent of sources. As has been found in other studies, though, women were far more likely than men to be identified in a story only by their marital or family status; 19 percent or 23 female sources were identified only this way as opposed to 4 percent of male sources, or 12 men. Women reporters were more likely than men reporters to identify both male and female news sources by family status ( 70 percent of this form of identification was in stories written by female reporters). The combined international findings were similar to New Zealand's in showing that 16 percent of female news subjects and 5 percent of male news subjects were identified only by their family status. However, globally there was no difference at all between male and female reporters when it came to identifying news subjects by family status.

\section{Images in the news}

In the New Zealand media monitored, men were more likely to appear in newspaper photographs: 17 percent of the 392 males as opposed to 14 percent of the 129 female news subjects. Thirty-one males were pictured compared to 10 females. Interestingly, global data showed 26 percent of female news subjects appeared in photographs compared with only 17 percent of males. While this still resulted in more males appearing in photographs, males appeared just twice as often as females in photographs worldwide, compared to three times as often in New Zealand. Additionally, the international analysis showed a difference between the way women and men were portrayed, supporting other studies that found photographs of women were used to titillate or excite, with pictures of women in a state of undress or accom- 
panied by suggestive headlines. However, in New Zealand, there were no sexualised pictures of females in the sample. The pictures did support a number of stereotypes, though, with men frequently portrayed 'on location' as active on tractors, moving furniture, renovating buildings, carrying crates and so on.

One story and accompanying picture, however, challenged gender stereotypes. A story from The Press, "'Grundy" girls just want to have fun', was about girls from a local girls' school who ran through a boys' college in sports gear, including underpants and bikinis, rugby shirts and shorts. They were reprimanded by their school, which was said to be 'disappointed' at the girls' behaviour. The girls' complaint was when the boys had done a similar thing it had been described as a 'hoot' (funny). They thought they were being treated differently to the boys when having fun. The photograph shows the young women in their rugby shorts and shirts, and bikini tops, with stripes painted on their bodies. Their arms are raised in strong, active poses-girls having fun in a strong, physical but non-sexualised way. In contrast, in a TV3 story about fashion at the NZ Trotting Cup function, the camera focused on female cleavage and high hemlines, and a lingering, low-level shot during a voice-over brought a voyeur's view of young women's legs and thighs.

\section{Discussion}

With the exception of a few brighter spots, such as the presence of female reporters and limited number of sexualised visuals, New Zealand's 2010 GMMP results are both disappointing and concerning. Perhaps unsurprisingly, the inclusion of online media in the sample did not alter this finding, with the online data mirroring that found in their offline equivalents (Comrie $\&$ McMillan, 2012). The stubbornly small percentage of women as news subjects - despite their prevalence in public life_-indicates we have reached some sort of plateau related to broader societal issues. Such conclusions are reinforced by the latest New Zealand census of women's participation: 2012 produced by the Human Rights Commission which notes 'New Zealand has lost its role as an international leader in progressing gender equality in terms of women's representation at the top in corporate and public governance, management and aspects of professional and public life' (p. 142). The report identifies weak target setting for women as part of the problem for systemic and frustrating low levels of female representation at the top and recom- 
mends affirmative action and quotas be seriously considered. The picture emerging from the census is of stagnation abetted by a sense of complacency. Additionally, women's equality is apparently off the agenda of key institutions and organisations (Simon-Kumar, 2011; Hyman, 2009). This finds its reflection in the historic and continuing GMMP results showing minute numbers of stories concerning gender issues in the New Zealand media. The Human Rights Commission report (2012) argues that public (and media) debate about gender equity reached a turning point in 2011 when the subsequently disgraced head of the Employers and Manufacturers Association made 'sublimely ridiculous comments linking women's menstruation to gender productivity' (p. 12). But coverage of the expanding pay gender gap was muted, reflecting the hierarchy of news values situating this story in the 'worthy but dull' category. That decision, however, also reflects lack of willingness to invest in 'women's' stories. Coverage could, for instance, have featured personal stories of women doing the same work as men for less pay.

From the 1980s it has been argued that journalistic practices and organisational routines of news production help maintain traditional gender roles (Turk, 1987). However, critique of coverage and news values underpinning the news agenda often runs up against media sensitivities about freedom of the press. Yet news values and choices prioritising conflict and scandal, 'hard news' such as crime, or events rather than underlying issues, not only fulfil commercial requirements. They, also when combined with routines of seeking out authoritative, easily-accessed and experienced news sources, enhance the presence of males in the news. These practices also ensure minorities are underrepresented in news, or in the case of Māori, for instance, appear largely in 'bad news' stories (Walker, 2002).

Scholars and some editors look for solutions in more diverse newsrooms, but whether this impacts on media content is less clear. Lavie \& Lehman-Wilzig (2005) review research on the effect of more female journalists on news content. They conclude that because of the importance of organisational (rather than individual) norms and work practices 'it is obvious that gender does not have a marked effect on the final news product - despite women journalists' inclinations to the contrary' (p. 73). Correa \& Harp (2011) are among those who argue it is only when women journalists 'achieve a critical mass, reach positions of influence or work in small organizations they may affect the priority, coverage and framing of the stories produced by the organization' (p. 301).

PACIFIC JOURNALISM REVIEW 19 (2) 2013209 
In New Zealand, the continuing comparatively strong presence of female news reporters is confirmed by Strong (2010) whose study of bylines in five metropolitan dailies (New Zealand Herald, Dominion Post, The Press, Otago Daily Times and Waikato Times) for July 2005 found women wrote 38 percent of articles. That figure rose to 48.7 percent for front page articles and 49.6 percent for national and local news (the area selected for GMMP sampling). But Strong's further analysis is particularly relevant to the broader concerns of this article. She found female bylines were fewer in senior reporting areas of business writing and in opinion pieces. Women wrote just 8.5 percent of sports articles and were reluctant to take up sports reporting largely because of male culture. Many male news managers and editors have spent time in the sports section and it forms a strong bond for collegial support. Strong's research showed female journalists entered the newsroom in significant numbers, performing well in 'hard' news sections. However, she describes an 'exodus' of female journalists early in their careers and very few women indeed in senior positions. Strong interviewed all nine women who had been editors of New Zealand dailies between 2000 and 2009. More than half left the position within three years. She concludes that to attract and maintain women in senior news positions requires systematic mentoring, developing a more transparent career path and improving training and management practices.

In New Zealand, codes of ethics address the issue of reporting gender. The EPMU (journalists' union) instructs journalists to 'not place unnecessary emphasis on gender, race, sexual preference, religious belief, marital status or physical or mental disability' (2008), while the Fairfax code refers to 'avoiding stereotyping' of a similar list (Fairfax Media NZ, 2011). Despite the codes, no doubt supported by most journalists, reporting remains unbalanced. Nor does journalism training address the issue. For instance the unit standards for the National Diploma in Journalism require students to produce a story related to Māori, while writing on a diverse society is one of a series of electives. Journalism schools generally teach 'diversity' in some sense, but with a crowded curriculum there is little evidence journalism trainers as a whole would be prepared to specifically tackle gendered reporting and how to avoid it. The commonly held journalistic view that gender is simply not relevant to many stories too easily translates into a reluctance to consider whether, in some cases, there is a gender angle worth exploring.

In November 2012 the International Federation of Journalists (IFJ), in 
association with the World Association for Christian Communication (WACC), launched a resource kit to promote gender-ethical journalism The resource emphasises that many news events affect men and women differently, and identifies two central reasons why gender-ethical journalism is necessary. First, it argues media play an important role in not only reporting news events but also in 'highlight[ing] the impact of what has happened on diverse sections of the people affected - especially those at most risk - so that action to deal with the situation can be equitable and responsive to the special needs of different groups' (International Federation of Journalists and World Association for Christian Communication, 2012 (a)). Second, attention is drawn to the media's democratic role in creating a public sphere in which issues of public interest are identified and discussed, and in which it is crucially important that women's voices are heard.

The IFJ and WACC guidelines for gender-ethical journalism across a range of story topics illustrate how a gender-lens can produce more balanced, informed and accurate reporting. In economic reporting, for example, journalists are encouraged to pay more attention to the way economic events such as budget announcements can affect men and women differently. Journalists are asked to 'figure out if the financial provisions and commitments in the budget are likely to promote or impede gender equality and equity, [and] whether the proposed distribution, use and generation of public resources are consistent with the human rights of women' (ibid (b), p. 10). In reporting stories concerning peace and security, the guidelines recommend journalists ask what the effects are on women. Across all news topics the guidelines recommend journalists make themselves aware of the differential effects of news events on different groups in society, including women, and develop a diverse list of news sources.

\section{Conclusion}

Over the last 15 years, the apparent stalling of women's representation in both positions of public power and in the news media has occurred during a time of great change in the media environment, as well as a decline in the visibility of the feminist 'movement'. Such developments have further complicated already complex relationships between media portrayals of women, societal attitudes to women, and women's ability and desire to challenge men's dominance in the economic, political and cultural spheres. 
Digital technologies have revolutionised communications, in some respects challenging limiting gender stereotypes and giving much greater agency to women, while in other respects reinforcing and extending such stereotypes. Debates within the various schools of feminism, moreover, demonstrate much disagreement over which developments have what effects.

A defining feature of digital media is that they allow users to generate, manipulate and disseminate data. This has opened up opportunities for individuals and groups, including women, to create content to communicate their voices and experiences directly. It has also seen the entrance of multiple new media players and platforms into the news media environment. Both developments have challenged the monopoly of the traditional news media and provide some basis for optimism that alternatives exist to news media in which women are marginalised.

It would, however, be premature to say digital technologies have rendered irrelevant the portrayal of women in the mainstream news media. One of the contradictory effects of the digital revolution is that it has amplified the role of the mainstream news media at the same time as challenging it, given both the penetration of the media into mobile devices and the constant re-broadcasting of news content via blogs, social media, twitter, tumblr, RSS feeds and so forth. Moreover, intense competition for audiences in a crowded media environment has seen a trend towards the tablodisation of news media content. The growing deployment of tabloid news values such as sex, celebrity, entertainment and showbiz (Harcup \& O'Neill, 2001; McGregor, 2002) leads to narratives that often depict women in stereotypical and frequently sexualised roles, the personalised aspect of which deflects attention away from the structural aspects of social inequality. This 'episodic'(Iyengar, 1994) form of news story-telling chimes with a neo-liberal worldview that sees success as largely determined by an individual's ability to maximise personal assets - intellectual or physical. Feminist objections to limited and stereotypical portrayals of women have, moreover, been muted by intra-feminist debate over whether 'women' in fact constitute a socially meaningful category (Gill \& Scharf, 2011; Gills, Howie \& Munford, 2007; Coleman, 2009).

Rapid and profound changes to media technologies, business models and players, combined with post-feminist and neo-liberal discourses, can disguise the fact that in the representation and participation of women in the news media much has remained the same. Data from the GMMP 
surveys continue to remind us that monitoring the gender gap in media news coverage remains a necessary task. As long as women's voices and experiences are under-represented in the New Zealand news media, the news will act as to maintain women's inequality rather than challenge it.

\section{References}

Byerly, C.M. (2004). Feminist interventions in news rooms. In K. Ross \& C.M. Byerly (Eds.), Women and media: International perspectives, (pp. 109-131). Blackwell: Oxford.

Coleman, J. (2009). An introduction to feminisms in a post-feminist age. Women's Studies Journal, 23 (2), 3-13.

Coleman, R., McCombs, M., Shaw, D., \& Weaver, D. (2008). Agenda setting. In K. Wahl-Jorgensen \& T. Hanitzsch (Eds.), The handbook of journalism studies (pp. 147-160). London: Routledge.

Comrie, M., \& McMillan, K. (2012). Who makes the news? New Zealand national report 2010. Global Media Monitoring Project, http://www.whomakesthenews. org/index.php/gmmp-2010/reports.

Correa, T., \& Harp, D. (2011). Why women matter in newsrooms: How power and critical mass relate to the coverage of the HPV vaccine. Journalism and Mass Communication Quarterly, 88(2), 301-319.

Entman, R.M. (2007). Framing bias: Media in the distribution of power. Journal of Communication 57, 163-173.

EPMU. (2008). Journalist code of ethics. Retrieved on March 12, 2013, from http:// www.epmu.org.nz/journalist-code-of-ethics/

Fairfax Media NZ. (2011). Journalism charter. Retrieved March 12, 2013, from http:// www.fairfaxmedia.co.nz/news/article.dot?id=36721

Gallagher, M. (2010). Forward. Who makes the news? Global Media Monitoring Project 2010. World Association for Christian Communication. Retrieved February12, 2013, from http://www.whomakesthenews.org/

Gill, R., \& Scharf, C. (Eds.). (2011). New femininities: Post-feminism, neo-liberalism and subjectivity. Hampshire and New York: Palgrave MacMillan.

Gills, S., Howie, G., \& Munford, R. (Eds.). (2007). Third wave feminism: A critical exploration (2nd ed.) Hampshire and New York: Palgrave MacMillan.

Harcup, T., \& O'Neill D. (2001). What is news? Galtung and Ruge revisited. Journalism Studies, 2 (2), 261-268.

Human Rights Commission. (2012). New Zealand census of women's participation 2012. Wellington: Human Rights Commission. Retrieved February 12, 2013, from http://live.isitesoftware.co.nz/neon2012/documents/hrc_womens_census2012.pdf

Hyman, P. (2009). Feminist agendas and action in 21st century New Zealand: Violence against women. In K. McMillan, J. Leslie, \& E. McLeay (Eds.), Rethinking women and politics:New Zealand and comparative perspectives (pp. 62-86). 
Wellington: Victoria University Press.

International Federation of Journalists and World Association for Christian Communication (2012) (a). Learning resource kit for gender ethical journalism and media house policy Book 1: Conceptual issues. Retrieved February 13, 2013, from http://www.ifj.org/assets/docs/238/231/e1396ee-58c86e7.pdf

International Federation of Journalists and World Association for Christian Communication (2012) (b). Learning resource kit for gender ethical journalism and media house policy Book 2: Practical resources. Retrieved February 13, 2013, from http://www.ifj.org/en/articles/wacc-and-ifj-launch-resource-kit-to-strengthengender-ethical-journalism.

Iyengar, S. (1994). Is anyone responsible? How television frames political issues. Chicago: University of Chicago Press.

Lavie, A., \& Lehman-Wilzig, S. (2005). The method is the message: Explaining inconsistent findings in gender and news production research. Journalism, 6(1), 66-89.

McGregor, J. (2002). 'Terrorism, war, lions and sex symbols: Restating news values'. In J. McGregor \& M. Comrie (Eds.). What's news? Reclaiming journalism in New Zealand, Palmerston North:, Dunmore Press.

Simon-Kumar, R. (2011). Differences that matter: From 'gender' to 'ethnicity' in contemporary Aotearoa New Zealand. Women's Study Journal, 25 (2), 74-90.

Strong, C. R. (2011). Female journalists in New Zealand daily newspapers: From early career to gender gap in editorship. Unpublished doctoral dissertation. Palmerston North: Massey University. Available http://mro.massey.ac.nz/handle/10179/2780

Turk, J. V. (1987). Sex-role stereotyping in writing the news. Journalism Quarterly, $64(2 / 3), 613-617$.

Walker, R. (2002). Māori news is bad news. In J. McGregor and M. Comrie (Eds.). What's news? Reclaiming journalism in New Zealand (pp.215-232). Palmerston North: Dunmore Press.

World Association for Christian Communication and Global Media Monitoring Project, Who makes the news? Retrieved February 13, 2013, from http://www. whomakesthenews.org/gmmp-background.html.

Dr Margie Comrie is an associate professor in the School of Communication, Journalism and Marketing at Massey University. Her research interests include political communication, journalism, and health communication. M.A.Comrie@massey.ac.nz

Dr Kate McMillan is a senior lecturer in politics at Victoria University of Wellington. She has two main research areas: media politics in New Zealand, and the politics of international migration and citizenship.

kate.mcmillan@vuw.ac.nz

214 PACIFIC JOURNALISM REVIEW 19 (2) 2013 